\title{
The Relationship between University Students' Music Preferences and Drug Abuse Tendencies and Personality Traits
}

\author{
Zühal Dinç Altun ${ }^{1, *}$, Kenan Bülbül ${ }^{2}$, Tuğba Türkkan ${ }^{3}$ \\ ${ }^{1}$ Faculty of Fatih Education, Trabzon University, Trabzon, Turkey \\ ${ }^{2}$ IMKB Primary School, Trabzon, Turkey \\ ${ }^{3}$ Department of Social Services, Faculty of Health Sciences, Gümüşhane University, Turkey
}

Copyright $\odot 2018$ by authors, all rights reserved. Authors agree that this article remains permanently open access under the terms of the Creative Commons Attribution License 4.0 International License

\begin{abstract}
The purpose of this study is to determine whether music preferences differ in terms of drug abuse tendencies and personality traits with regard to the type of music that music teacher candidates listen to. The research group of the study was comprised of 141 university students. Research data were collected using the Substance Use Tendency Scale, the Adjective-Based Personality Test (ABPT), and the Personal Information Form developed by the researchers. Pop music (93.6\%) was determined to be the music type most listened to, and Heavy Metal music (21.3\%) music the type least listened to. While the students were determining their music preferences, they indicated that the moods (99.3\%) and the melody of the music (98.6\%) were primarily important. The results of the analysis show that there are significant differences in music preferences based on the tendency for drug abuse and on personality traits. Findings have been discussed in the light of the relevant literature, and proposals have been made to professionals working in the fields of research, music therapy and music education.
\end{abstract}

Keywords Drug Abuse Tendency, Students, Music Preference, Personality Traits

\section{Introduction}

Having a universal character because it is existent in all societies, music is one of the most powerful expression instruments of feelings. Today, it is perpetually emphasized that music, which is encountered in public places, in hotels, in shopping centers, in restaurants, even from transport facilities to health centers and in every area of life, has a psychological effect on people. In that case, is there any relation between music, which is used in many areas with different functions today, and personality and behavior? What determines the kind of music that we love? What is the reason for having different musical preferences even among siblings living in the same house? Why does someone love pop music while the other loves arabesque? Why do we forget some melodies easily while we keep others in mind? In order to determine the effects of music on human beings, such questions have been asked, and the answers to them have been sought, in an ongoing way since ancient times.

Research shows that music is very effective on human psychology. Among these studies, shopping behaviors [48], personality traits [14], suicide [28], depression [9] and drug abuse [50] are related to music preferences. Music has been used to influence people's feelings in types of events that have happened in wars, in religious rituals, and in entertainment for ages. It is also known that some musical genres in particular have different effects on individuals and are associated with risky behaviors. For example, adolescents who listened to heavy metal music were found to be experiencing behavior problems at school, using drugs and alcohol, and engaging in illegal activities [44]. Ögel et al. [34] stated that adolescents with multiple drug abuse and frequent use of marijuana prefer rap, hip hop, and techno-style music. One of the most concrete examples of this is the lyrics of the song "Heroin", which Lou Reed sang in 1974. When we look at the words of the song, the use of a drug substance in general, a negative point of view towards life and an opposition emphasis on social order and traditions are clearly visible. In this respect, it is a hint as to how music influences and engraves the way of thinking and personality of individuals. Specially conducted" studies show that adolescents with psychological problems and young adolescents in their late adolescence prefer to listen to heavier music styles such as heavy metal and hard rock $[22,46]$ 
Investigations conducted by Rentfrow and Gosling [35] in order to determine the relationship between personality traits and music preferences reveal that listeners of hard and rebellious music such as rock and heavy metal are the ones who like to exhibit risky behaviors and are curious about experiencing physically different things; while people who listen to traditional or upbeat music, such as pop, are social, cheerful, helpful, reliable, and find themselves physically attractive. Individuals who listen to music with energetic and rhythmic levels, like rap, hip hop and funk, love to talk, forgive, find themselves physically attractive and are energetic; while people who listen to more reflective and complicated music such as blues, jazz, folk and classical music are those who are interested in trying something new and open, whose verbal skills are strong, and who they feel intelligent, but whose physical skills are the opposite of these features. As a result, it can be seen that music can influence people in ways ranging from their behavior to their thoughts, from their clothing styles to their friendships, and can even influence the question of whether to maintain their lives or not.

The aim of this study is to investigate whether music teacher candidates' preferences of music differ according to their tendencies towards using drugs or their personality traits. In a recent study conducted by Bülbül [11], it is emphasized that $59.4 \%$ of the adolescents participating in the research have a tendency towards using drugs. This is a remarkably high rate. In other words, one out of two adults seem to be prone to drug abuse. In this respect it is important to determine whether the music preferences of the individuals participating in the research are related to their drug abuse tendencies and in this sense, it is thought that the practitioners will provide hints. On the other hand, personality traits such as being introvert or extrovert, being open to try new things, being tender-minded, having responsibility or having emotional instability such as neuroticism, are directly related to musical preferences that appeal to our emotions, which can lead to changes in our behaviors and our lifelong outlook. When the studies conducted in this context were examined, it was observed that the preferences for music, drug abuse and personality characteristics were examined separately, while the result was that the tendency towards using drugs and personality characteristics were not examined together. It is thought that the research that is done will fill the gap in the literature and will contribute to future studies.

\section{Method}

\subsection{Research Pattern}

This study aimed to examine musical preferences of music teacher candidates in terms of substance use tendencies and personality traits. This study is a quantitative research study which is compatible with a causal-comparative pattern. In causal-comparative studies, which are a type of relational research, researchers aim to determine whether two or more groups differ in terms of a particular variable. The sources of the differences which arise in such research are not attempted to be identified [17]. For this purpose, the following sub-goals were sought in the research:

1. Does the preference of music of the university students differ based on gender?

2. Does the tendency of students towards using substances differ based on music preferences?

3. Do the personality traits of university students differ based on their preference of music?

Table 1. Information about music genres and the frequency of listening

\begin{tabular}{|l|l|l|l|l|}
\hline \multirow{2}{*}{ Music Genre } & \multicolumn{2}{|l}{ Does not Listen } & Listens & Percentage (\%) \\
\cline { 2 - 5 } & Frequency (f) & Percentage (\%) & Frequency (f) & 93.6 \\
\hline Pop & 9 & 6.4 & 132 & 63.1 \\
\hline Jazz & 52 & 36.9 & 89 & 75.9 \\
\hline Arabesque & 34 & 24.1 & 107 & 50.4 \\
\hline Rock & 70 & 49.6 & 71 & 21.3 \\
\hline Heavy Metal & 111 & 78.7 & 30 & 40.4 \\
\hline Rap & 84 & 59.6 & 57 & 81.6 \\
\hline Turkish Folk Music & 26 & 18.4 & 115 & 83.7 \\
\hline Turkish Classical Music & 23 & 16.3 & 118 & 81.6 \\
\hline Classical Music & 26 & 18.4 & 115 & 31.2 \\
\hline Sufi Music & 97 & 68.8 & 44 & 22.7 \\
\hline Hip Hop & 109 & 77.3 & 32 & 90.8 \\
\hline Slow & 13 & 9.2 & 128 & 34.0 \\
\hline R\&B & 93 & 66.0 & 48 & 50.4 \\
\hline Blues & 70 & 49.6 & 71 & \\
\hline
\end{tabular}




\subsection{Study Group of the Research}

The study group consisted of 141 students; 53 male students (37.6\%) and 88 female students (62.4\%) who were studying in the Music Teaching Department of at a faculty of education in Turkey during the fall semester of the 2017-2018 academic year. Among the descriptive findings related to the research, information about the listening conditions for music genres and the factors affecting the music preferences are included. It is reported that the music genres most listened to are 132 (93.6\%) Pop, 128 (90.8\%) Slow, 118 (83.7\%) Turkish Classical Music, 115 (81.6\%) Turkish Folk Music and Western Classical Music. 30 (21.3\%) Heavy Metal, 32 (22.7\%) Hip Hop, 44 (31.2\%) Sufi and 48 (34.0\%) R \& B are among the music genres they listened to the least (Table 1). On the other hand, it was detected that their mood (99.3\%), the melody of the music $(98.6 \%)$ and the lyrics (93.6\%) were important for the majority of the participants while choosing what to listen to (Table 2).

\subsection{Data Collection Tool of the Research}

The Personal Information Form, Substance Use Tendency Scale and Adjective-Based Personality Test were used in order to collect data.

Personal Information Form: The personal information form prepared by the researchers aims to collect some demographic information of the university students participating in the study. In this respect, expressions, which gender, the listening conditions for musical genres and elements affecting music preferences are asked for and included in the personal information form.

Substance Use Tendency Scale: The Substance Use Tendency Scale was developed by MacAndrew[27], derived from the MMPI. The original name is the Substance Abuse Proclivity Scale (SAP) and the scale consists of 36 questions. The person who scores 16 or more points on it tends to use substances. Ceyhun, Oğuztürk and
Ceyhun[13] found a correlation coefficient of .49 between the MacAndrew[27] Alcoholism Scale and the Substance Use Tendency Scale as the concurrent validity criterion in their validity study. As a discriminant validity measure, the Substance Use Tendency Scale correctly classified $84 \%$ of drug addicts, $65 \%$ of alcohol addicts, $40.5 \%$ of psychiatrists and $41.5 \%$ of norms. The scale was administered twice to 60 patients every 5 weeks, and the test-retest reliability was analyzed by the Pearson Moments Multiplication Correlation technique. Accordingly, the total score correlation of the scale was found to be .63.

Adjective-Based Personality Test (ABPT): The Adjective-Based Personality Test (ABPT) was developed by Bacanl, İlhan and Aslan[4] based on five-factor theory. The ABPT consists of 40 items based on pairs of opposite adjectives. The scale items have two poles. However, the response is made in 1-7 Likert style. Bipolar items are evaluated according to the points taken on a 7-point scale. As a result of the factor analysis made, we can see a five-factor structure: extroversion (e.g. "preferring loneliness-loving the crowd"), tender-mindedness (e.g. "vindictive-merciful"), responsibility (e.g. "irregular-regular"), emotional imbalance (e.g. "calm-nervous") and experiential openness (e.g. "not interested in art-interested in art"). It was seen that the five factors accounted for $52.63 \%$ of the total variance of the scale. In the reliability study of the ABPT, the reliability coefficients obtained with the test repetition method for each subscale were .85 for extroversion, .86 for tender-mindedness, .71 for responsibility, .85 for emotional imbalance and .68 for empirical clarity. The Cronbach Alpha coefficients are .89 for extroversion, .87 for tender-mindedness, .88 for responsibility, .73 for emotional imbalance, and .80 for empirical clarity. The Cronbach Alpha coefficients obtained for this study are 89 for extroversion, .78 for tender-mindedness, .80 for responsibility, .74 for emotional imbalance, and .77 for empirical clarity.

Table 2. Information related to the determinants of music preferences

\begin{tabular}{|l|l|l|l|l|}
\hline \multirow{2}{*}{ Determinants of Music Preference } & \multicolumn{2}{l}{ Does Not Matter } & \multicolumn{2}{l|}{ Matters } \\
\cline { 2 - 5 } & Frequency (F) & Percentage (\%) & Frequency (F) & Percentage (\%) \\
\hline The Lyrics & 9 & 6.4 & 132 & 93.6 \\
\hline The Melody & 2 & 1.4 & 139 & 98.6 \\
\hline The Genre & 13 & 9.2 & 128 & 90.8 \\
\hline The Singer & 20 & 14.2 & 121 & 85.8 \\
\hline How Popular They Are & 85 & 60.3 & 56 & 39.7 \\
\hline Advice of a Friend & 18 & 12.8 & 123 & 87.2 \\
\hline My Mood & 1 & 0.7 & 140 & 99.3 \\
\hline
\end{tabular}


Table 3. Ruggedness and Skewness Coefficients Related to Measuring Instruments

\begin{tabular}{|c|c|c|c|c|c|c|c|c|c|c|}
\hline & & \multirow{2}{*}{$\mathrm{N}$} & \multirow{2}{*}{ Min. } & \multirow{2}{*}{ Max. } & \multirow{2}{*}{$\mathrm{X}$} & \multirow{2}{*}{ Ss } & \multicolumn{2}{|c|}{ Skewness } & \multicolumn{2}{|c|}{ Ruggedness } \\
\hline & & & & & & & Value & Error & Value & Error \\
\hline \multirow{6}{*}{ ABPT } & Total & 141 & 92 & 254 & 201.18 & 29.43 & -.83 & .20 & .84 & .40 \\
\hline & Neuroticism & 141 & 7 & 43 & 24.66 & 7.30 & .32 & .20 & .01 & .40 \\
\hline & Extroversion & 141 & 17 & 63 & 46.05 & 10.48 & -.29 & .20 & -.47 & .40 \\
\hline & $\begin{array}{l}\text { Experiential } \\
\text { Openness }\end{array}$ & 141 & 22. & 56 & 44.74 & 7.31 & -.75 & .20 & .29 & .40 \\
\hline & Tender- Mindedness & 141 & 23 & 63 & 49.48 & 9.14 & -.72 & .20 & -.01 & .40 \\
\hline & Responsibility & 141 & 13 & 49 & 36.23 & 8.41 & -.64 & .20 & -.22 & .40 \\
\hline SUTS & & 141 & 8 & 27 & 15.90 & 3.75 & .30 & .20 & .11 & .40 \\
\hline
\end{tabular}

ABPT: Adjective-Based Personality Test; SUTS: Substance Use Tendency Scale

\subsection{Statistical Approach}

Before analyzing the data obtained within the scope of the research, a number of statistical arrangements had to be made. In this context, missing value analysis and normal distribution analysis were carried out [16]. As 3 scales were incomplete or incorrectly answered, they were not included in the analysis. Data analysis was conducted with 141 students. The normality hypothesis implies that the result is related to the observed data of a variant with the degree of normal distribution fit [16]. In this study, the skewness and kurtosis values of the variables were examined and whether the normal distribution was appropriate or not was examined. Regarding normality, it can be seen in the literature that the values of skewness are between -1.5 and +1.5 [43]. Accordingly, when the data in Table 3 are examined, it is noteworthy that all the skewness and skewness values are within the specified range. In this respect, it was concluded that each of the variables in the study had normal distribution and met the normality assumption (Table 3).

\section{Findings}

On the basis of first research question findings of differences in students' musical preferences based on gender and drug use tendencies were analyzed using chi-square test. Results are presented in Table 4 below.

As can be seen from the Table 4, Heavy Metal (x2 (1, N $=141)=8.15, \mathrm{p}<.05)$, Turkish Folk Music $(\mathrm{x} 2(1, \mathrm{~N}=141)$ $=6.69, \mathrm{p}<.05)$ and Sufi Music $1, \mathrm{~N}=141)=7.83, \mathrm{p}<.05$ ) were differentiated on the basis of gender (Table 4). It is shown that the ratio of male students who listen to Heavy
Metal as the main cause of these differences is higher than that of male students who listen to Turkish Folk Music compared to female students who listen to Turkish Folk Music and that the ratio of female students who do not listen to Sufi Music is higher than that of non-listening male students.

On the other hand, the chi-square test was used to determine the differences between students' musical preferences based on drug abuse tendencies. According to the substance use tendency scale, students were classified as inclined and non-inclined according to 16 cut-off points. According to this, it was determined that Turkish Folk Music differed on the basis of tendency towards using substance $(\mathrm{x} 2(1, \mathrm{~N}=141)=5.29, \mathrm{p}<.05)($ Table 4$)$. It can be shown as the source of this difference that the rates of those listening to Turkish Folk music that tend to use substances are higher than those of Turkish Folk Music listeners who do not tend to use substances.

The independent $t$ test was used to determine the differences in the personality traits of the students based on their musical genres. Personality traits were examined as 5 sub-dimensions: Neuroticism (N), Extroversion (E), Experiential Openness (EO), Compliance (C) and Responsibility (R). As shown in Table 5, it was found that the neurotic personality characteristics were significantly different in the music types of Jazz $(\mathrm{t}(139)=2.33, \mathrm{p}<.05)$ and Blues ( $t(139)=1.98, p<.05)$. It can be expressed as the source of this difference that the average of the neurotic points of the non-blues listeners $(X=25.88$, SS $=$ $7.94)$ is higher than that of the listeners $(X=23.46$, $S S=$ 6.44) and the average of the neurotic points of the non-jazz listeners $(X=26.51, S S=7.61)$ is higher than in those who listen $(X=23.58, S D=6.92)$. 
Table 4. Findings Related to Differences in Music Preferences Based on Gender and Tendency to Use Substances

\begin{tabular}{|c|c|c|c|c|c|c|c|c|c|c|c|c|c|c|c|}
\hline & & \multicolumn{4}{|c|}{ Gender } & \multirow{3}{*}{$\mathrm{X}^{2}$} & \multirow{3}{*}{ Sd } & \multirow{3}{*}{$\mathrm{p}$} & \multicolumn{4}{|c|}{$\begin{array}{l}\text { Tendency Towards Drug } \\
\text { Abuse }\end{array}$} & \multirow{3}{*}{$\mathrm{X}^{2}$} & \multirow{3}{*}{$\mathrm{Sd}$} & \multirow{3}{*}{$\mathrm{p}$} \\
\hline & & \multicolumn{2}{|c|}{ Male } & \multicolumn{2}{|c|}{ Female } & & & & \multicolumn{2}{|c|}{ Existent } & \multicolumn{2}{|c|}{ Non-Existent } & & & \\
\hline & & $\mathrm{N}$ & $\%$ & $\mathrm{~N}$ & $\%$ & & & & $\mathrm{~N}$ & $\%$ & $\mathrm{~N}$ & $\%$ & & & \\
\hline \multirow{2}{*}{ Pop } & $\begin{array}{l}\text { Does not } \\
\text { listen }\end{array}$ & 8 & 15.1 & 6 & 6.8 & \multirow{2}{*}{2.53} & \multirow{2}{*}{1} & \multirow{2}{*}{.11} & 8 & 13.1 & 6 & 7.5 & \multirow{2}{*}{1.22} & \multirow{2}{*}{1} & \multirow{2}{*}{.26} \\
\hline & Listens & 45 & 84.9 & 82 & 93.2 & & & & 53 & 86.9 & 74 & 92.5 & & & \\
\hline \multirow{2}{*}{ Jazz } & $\begin{array}{l}\text { Does not } \\
\text { listen }\end{array}$ & 19 & 35.8 & 33 & 37.5 & \multirow{2}{*}{.03} & \multirow[t]{2}{*}{1} & \multirow[t]{2}{*}{.84} & 20 & 32.8 & 32 & 40.0 & \multirow[t]{2}{*}{.77} & \multirow[t]{2}{*}{1} & \multirow[t]{2}{*}{.37} \\
\hline & Listens & 34 & 64.2 & 55 & 62.5 & & & & 41 & 67.2 & 48 & 60.0 & & & \\
\hline Arabesque & $\begin{array}{l}\text { Does not } \\
\text { listen }\end{array}$ & 10 & 18.9 & 24 & 27.3 & 1.27 & 1 & .25 & 13 & 21.3 & 21 & 26.3 & .46 & 1 & .49 \\
\hline & Listens & 43 & 81.1 & 64 & 72.7 & & & & 48 & 78.7 & 59 & 73.8 & & & \\
\hline Rock & $\begin{array}{l}\text { Does not } \\
\text { listen }\end{array}$ & 26 & 49.1 & 44 & 50.0 & .01 & 1 & .91 & 31 & 50.8 & 39 & 48.8 & .05 & 1 & .80 \\
\hline & Listens & 27 & 50.9 & 44 & 50.0 & & & & 30 & 49.2 & 41 & 51.3 & & & \\
\hline Heavy Metal & $\begin{array}{l}\text { Does not } \\
\text { listen }\end{array}$ & 35 & 66.0 & 76 & 86.4 & 8.15 & 1 & $.00 *$ & 45 & 73.8 & 66 & 82.5 & 1.57 & 1 & .21 \\
\hline & Listens & 18 & 34.0 & 12 & 13.6 & & & & 16 & 26.2 & 14 & 17.5 & & & \\
\hline Rap & $\begin{array}{l}\text { Does not } \\
\text { listen }\end{array}$ & 31 & 58.5 & 53 & 60.2 & .04 & 1 & .83 & 35 & 57.4 & 49 & 61.3 & .21 & 1 & .64 \\
\hline & Listens & 22 & 41.5 & 35 & 39.8 & & & & 26 & 42.6 & 31 & 38.8 & & & \\
\hline Turkish Folk & $\begin{array}{l}\text { Does not } \\
\text { listen }\end{array}$ & 4 & 7.5 & 22 & 25.0 & 6.69 & 1 & $.01 *$ & 6 & 9.8 & 20 & 25.0 & 5.29 & 1 & $.02 *$ \\
\hline & Listens & 49 & 92.5 & 66 & 75.0 & & & & 55 & 90.2 & 60 & 75.0 & & & \\
\hline $\begin{array}{l}\text { Turkish } \\
\text { Classical }\end{array}$ & $\begin{array}{l}\text { Does not } \\
\text { listen }\end{array}$ & 9 & 17.0 & 14 & 15.9 & .02 & 1 & .86 & 10 & 16.4 & 13 & 16.3 & .00 & 1 & .98 \\
\hline Music & Listens & 44 & 83.0 & 74 & 84.1 & & & & 51 & 83.6 & 67 & 83.8 & & & \\
\hline Classical & $\begin{array}{l}\text { Does not } \\
\text { listen }\end{array}$ & 12 & 22.6 & 14 & 15.9 & .99 & 1 & .31 & 13 & 21.3 & 13 & 16.3 & .59 & 1 & .44 \\
\hline Music & Listens & 41 & 77.4 & 74 & 84.1 & & & & 48 & 78.7 & 67 & 83.8 & & & \\
\hline Sufi Music & $\begin{array}{l}\text { Does not } \\
\text { listen }\end{array}$ & 29 & 54.7 & 68 & 77.3 & 7.83 & 1 & $.00 *$ & 40 & 65.6 & 57 & 71.3 & .51 & 1 & .47 \\
\hline & Listens & 24 & 45.3 & 20 & 22.7 & & & & 21 & 34.4 & 23 & 28.8 & & & \\
\hline Нiр Нор & $\begin{array}{l}\text { Does not } \\
\text { listen }\end{array}$ & 40 & 75.5 & 69 & 78.4 & .16 & 1 & .68 & 45 & 73.8 & 64 & 80.0 & .76 & 1 & .38 \\
\hline & Listens & 13 & 24.5 & 19 & 21.6 & & & & 16 & 26.2 & 16 & 20.0 & & & \\
\hline Slow & $\begin{array}{l}\text { Does not } \\
\text { listen }\end{array}$ & 5 & 9.4 & 9 & 10.2 & .02 & 1 & .87 & 5 & 8.2 & 9 & 11.3 & .36 & 1 & .54 \\
\hline & Listens & 48 & 90.6 & 79 & 89.8 & & & & 56 & 91.8 & 71 & 88.8 & & & \\
\hline $\mathrm{R} \& \mathrm{~B}$ & $\begin{array}{l}\text { Does not } \\
\text { listen }\end{array}$ & 32 & 60.4 & 61 & 69.3 & 1.17 & 1 & .27 & 39 & 63.9 & 54 & 67.5 & .19 & 1 & .65 \\
\hline & Listens & 21 & 39.6 & 27 & 30.7 & & & & 22 & 36.1 & 26 & 32.5 & & & \\
\hline Blues & $\begin{array}{l}\text { Does not } \\
\text { listen }\end{array}$ & 23 & 43.4 & 47 & 53.4 & 1.32 & 1 & .24 & 29 & 47.5 & 41 & 51.3 & .19 & 1 & .66 \\
\hline & Listens & 30 & 56.6 & 41 & 46.6 & & & & 32 & 52.5 & 39 & 48.8 & & & \\
\hline
\end{tabular}


The Relationship between University Students' Music

Preferences and Drug Abuse Tendencies and Personality Traits

Table 5. Findings about differences in personality traits based on music preferences

\begin{tabular}{|c|c|c|c|c|c|c|c|c|c|}
\hline Variable & & Factor & $\mathrm{N}$ & $\mathrm{X}$ & SS & Sd & $\mathrm{t}$ & $\mathrm{p}$ & Cohen's d \\
\hline \multirow{2}{*}{ Jazz } & \multirow{2}{*}{$\mathrm{N}$} & $\begin{array}{l}\text { Does not } \\
\text { listen }\end{array}$ & 52 & 26.51 & 7.61 & \multirow{2}{*}{139} & \multirow{2}{*}{2.33} & \multirow{2}{*}{.02} & \multirow{2}{*}{.40} \\
\hline & & Listens & 89 & 23.58 & 6.92 & & & & \\
\hline \multirow{6}{*}{$\begin{array}{l}\text { Turkish } \\
\text { Classical } \\
\text { Music }\end{array}$} & \multirow[t]{2}{*}{ E } & $\begin{array}{l}\text { Does not } \\
\text { listen }\end{array}$ & 23 & 41.91 & 10.82 & \multirow[t]{2}{*}{139} & \multirow[t]{2}{*}{-2.09} & \multirow[t]{2}{*}{.03} & \multirow[t]{2}{*}{-.46} \\
\hline & & Listens & 118 & 46.86 & 10.26 & & & & \\
\hline & \multirow[t]{2}{*}{$\mathrm{EO}$} & $\begin{array}{l}\text { Does not } \\
\text { listen }\end{array}$ & 23 & 41.69 & 8.98 & \multirow[t]{2}{*}{139} & \multirow[t]{2}{*}{-2.21} & \multirow[t]{2}{*}{.02} & \multirow[t]{2}{*}{-.45} \\
\hline & & Listens & 118 & 45.33 & 6.84 & & & & \\
\hline & \multirow[t]{2}{*}{$\mathrm{C}$} & $\begin{array}{l}\text { Does not } \\
\text { listen }\end{array}$ & 23 & 46.17 & 10.43 & \multirow{2}{*}{139} & \multirow{2}{*}{-1.91} & \multirow{2}{*}{.05} & \multirow{2}{*}{-.40} \\
\hline & & Listens & 118 & 50.12 & 8.77 & & & & \\
\hline \multirow{2}{*}{$\begin{array}{l}\text { Western } \\
\text { Classical } \\
\text { Music }\end{array}$} & \multirow[t]{2}{*}{$\mathrm{EO}$} & $\begin{array}{l}\text { Does not } \\
\text { listen }\end{array}$ & 26 & 41.65 & 8.90 & \multirow[t]{2}{*}{139} & \multirow[t]{2}{*}{-2.42} & \multirow[t]{2}{*}{.01} & \multirow[t]{2}{*}{-.47} \\
\hline & & Listens & 115 & 45.44 & 6.75 & & & & \\
\hline \multirow{6}{*}{$\begin{array}{l}\text { Sufi } \\
\text { Music }\end{array}$} & \multirow[t]{2}{*}{$\mathrm{EO}$} & $\begin{array}{l}\text { Does not } \\
\text { listen }\end{array}$ & 97 & 44.02 & 8.03 & \multirow[t]{2}{*}{123} & -2.06 & .04 & -.34 \\
\hline & & Listens & 44 & 46.34 & 5.14 & & & & \\
\hline & $\mathrm{C}$ & $\begin{array}{l}\text { Does not } \\
\text { listen }\end{array}$ & 97 & 48.11 & 9.55 & 105 & -2.96 & .00 & -.51 \\
\hline & & Listens & 44 & 52.50 & 7.39 & & & & \\
\hline & $\mathrm{R}$ & $\begin{array}{l}\text { Does not } \\
\text { listen }\end{array}$ & 97 & 35.10 & 8.80 & 104 & -2.63 & .01 & -.45 \\
\hline & & Listens & 44 & 38.72 & 6.91 & & & & \\
\hline & E & $\begin{array}{l}\text { Does not } \\
\text { listen }\end{array}$ & 14 & 39.00 & 7.77 & 139 & -2.71 & .00 & -.84 \\
\hline & & Listens & 127 & 46.83 & 10.47 & & & & \\
\hline & EO & $\begin{array}{l}\text { Does not } \\
\text { listen }\end{array}$ & 14 & 38.00 & 7.65 & 139 & -3.80 & .00 & -1.02 \\
\hline Slo & & Listens & 127 & 45.48 & 6.91 & & & & \\
\hline Slow & C & $\begin{array}{l}\text { Does not } \\
\text { listen }\end{array}$ & 14 & 41.78 & 8.70 & 139 & -3.44 & .00 & -.97 \\
\hline & & Listens & 127 & 50.33 & 8.81 & & & & \\
\hline & $\mathrm{R}$ & $\begin{array}{l}\text { Does not } \\
\text { listen }\end{array}$ & 14 & 31.35 & 9.20 & 139 & -2.32 & .02 & -.62 \\
\hline & & Listens & 127 & 36.77 & 8.18 & & & & \\
\hline Blues & $\mathrm{N}$ & $\begin{array}{l}\text { Does not } \\
\text { listen }\end{array}$ & 70 & 25.88 & 7.94 & 139 & 1.98 & .04 & .33 \\
\hline & & Listens & 71 & 23.46 & 6.44 & & & & \\
\hline
\end{tabular}

*As the 14 different music preferences and 5 different personality traits cover about 3 pages when the independent $t$ test analyses are tabulated, only the significant values are given

It was found that the personality trait of Extroversion was significantly different according to Turkish Classical Music (t (139) $=-2.09, \mathrm{p}<.05)$ and Slow (t (139) $=-2.71$, $\mathrm{p}<.05$ ) music types. As a source of this difference, it can be shown that the average score of extroversion points of Turkish Classical Music listeners $(X=46.86, S S=10.26)$ is higher than in those who do not listen $(X=41.91$, SS = 10.82) and the average extroversion score of Slow Music listeners $(X=46.83$, SS $=10.47)$ is higher than that of non-listeners $(X=39.00, \mathrm{SS}=7.77)$.

It was revealed that the personality characteristics of Experiential Openness differed respectively according to Turkish Classical Music (t (139) $=-2.21, \mathrm{p}<.05$ ), Western Classical Music (t $(139)=-2.42, \mathrm{p}<.05)$, Sufi Music $(\mathrm{t}$
$(123)=-2.06, \mathrm{p}<.05)$ and Slow $(\mathrm{t}(139)=-3.80, \mathrm{p}<.05)$. It can be expressed as a source of this significant difference that the experiential openness average score of Turkish Classical Music listeners $(X=45.33, \mathrm{SD}=6.84)$ is higher than that of the non-listeners $(X=41.69, \mathrm{SD}=$ 8.98), the experiential openness average score of Western Classical Music listeners ( $X=45.44$, SS $=6.75$ ) is higher than the score of the non-listeners ( $X=41.65$, SS $=8.90)$, the experiential openness average score of Sufi Music listeners $(X=46.34$, SS $=5.14)$ is higher than the score of the non-listeners $(X=44.02, \mathrm{SS}=8.03)$, and the experiential openness average score of Slow Music listeners $(X=45.48, S S=6.91)$ is higher than the score of the non-listeners $(X=38.00$, SS= 7.65). 
It was discovered that the Compatibility personality trait had a significant difference in regard to Turkish Classical Music, Sufi Music and Slow Music. It can be expressed as a source of this significant difference that the compatibility average score of Turkish Classical Music listeners $(X=50.12$, SS $=8.77)$ is higher than in those who do not listen $(X=46.17, S D=10.43)$, the compatibility average score of Sufi Music listeners (X = 52.50 , $\mathrm{SS}=7.39)$ is higher than that of non-listeners $(X=$ 48.11 , SS $=9.55)$ and the compatibility average score of Slow Music listeners $(X=50.33$, SS $=8.81)$ is higher than that of non-listeners $(X=41.78, \mathrm{SS}=8.70)$.

Finally, it has been found that the Responsibility personality trait has a significant difference based on musical types such as Sufism (t $(104)=-2.63, \mathrm{p}<.05)$ and Slow $(\mathrm{t}(139)=-2.32, \mathrm{p}<.05)$. It can be expressed as a source of this significant difference that the responsibility average point of Slow Music listeners ( $\mathrm{X}=36.77$, SS = 8.18) is higher than the average score of non-listeners (X $=31.35$, $\mathrm{SS}=$, SS $=9.20)$, and the responsibility average point of Sufi Music listeners $(X=38.72$, $S S=6.91)$ is higher than in those who do not listen to $(X=35.10$, SS= 8.80).

\section{Discussion}

In accordance with the purpose of the research, it was determined by various statistical analyses whether the music listening preferences of the students in the music education department differed in terms of substance use tendencies and personality traits according to their musical genres. The obtained results show that the preference of music style differs in terms of some variables.

As a result of these analyses, a significant relationship was found between preference of Turkish Folk Music and tendency towards drug abuse. When the relevant literature was examined, it was observed that the studies conducted were not consistent with the results of this study. Adolescents who listen to Heavy Metal music were reported to be experiencing behavior problems at school, using substances and alcohol, and engaging in illegal activities [44]. Similarly, Arnett [2] found that male adolescents who liked heavy metal music exhibited more extensive reckless behavior, including driving, sexual behavior, and drug abuse, than those who dislike this music. King [25], in a study of adolescents in a psychiatric population, found that especially people who are physically addicted to drugs prefer to listen to heavy metal music. According to King [25], young people who cannot identify with traditional values find simple but non-traditional solutions to their complex problems in the lyrics of this kind of music. Ögel and others [34] reported in their study that adolescents with more than one substance use and frequent use of marijuana prefer rap, hip hop, techno, and dance music. On the other hand, the songs of folk music are mostly about homesickness, longing, loneliness and so on and it can be said that they often express emotions, and these parts stir up negative emotions in the individuals listening to this genre. In addition, in a study conducted, it was stated that the psychological symptom levels of Turkish Folk Music listeners were higher than in those who preferred to listen to other types of music, and it was stated that Turkish folk music had a serious negative effect on psychological symptoms [41]. Roberts, Dimsdale, East, and Friedman[36] found that as emotional reactions to music increase, risk-taking behaviors increase in individuals. These results support the findings of this research. Nevertheless, it is suggested that by keeping the sample group broader and with a study group that takes regional differences into consideration, a more inclusive study can be conducted.

When the music genres which students listen to are examined, it is stated that Turkish pop music is the most popular music genre. The kind of music they least listening is heavy metal. When the results favor pop music [3], it is considered that as well as the tremendous development of the technology and music industry, making accessibility of listening easier is influential because pop music is more entertainment-oriented than defending a particular attitude or idea. In addition, adolescents take the individuals they see as model figures. Popular music and stars are important role models in this sense [39]. The result of the youths choosing the pop music genre the most resembles other national and international studies conducted among university students $([1,3,5,8,10,23,38,39,45,47,49]$ When the relevant literature is examined, it is seen that pop music is the most popular music among young people in many studies. In addition, Frith[51] states that adolescents created various subcultures around pop music because they see music as a symbol for sharing their values, attitudes and thoughts [32]. The reason of including $\mathrm{R} \& \mathrm{~B}$, heavy metal, and jazz / blues in this study is that it can be considered that these species are not well recognized and therefore cannot gain enough attention from the point of view of the students. When the music genres played by the students were evaluated according to sex, it was stated that the ratio of listening to Turkish Folk Music differed on the basis of sex and that the ratio of male students listening to Turkish Folk Music was higher than that of the female students who listened. In this case, it is understood that male students preferred traditional Turkish music. It has been observed in the literature that there are parallel studies with the results of this study. In the study of relationships between art school students' level of loneliness and their music preference conducted by Güven[20], the ratio of boys listening to Turkish Folk Music was $12.3 \%$ and the rate of girls was $4 \%$. Similarly, according to the results of the study of Sağır and 
Öztürk[38], the percentage of Turkish Classical Music listeners was $62.0 \%$ for males and $38.0 \%$ for females. Ulutürk[45] found that 11 of the 16 students who listened to Turkish Folk Music were male and 5 were girls, although there was no significant difference between them. In accordance with the revision of the Turkish Folk Music pieces in accordance with the general demands of the mass of listeners; the popular singers voicing these works and the lyrics of these works evoking a sense of belonging by having cultural elements such as values and traditions; as well as perceptions of social reality between men and women due to the attitudes and value judgments they have developed within the socialization process, it is thought that men listen to Turkish Folk Music more.

Among the research results, the proportion of men who listened to heavy metal music was found to be higher than the rate of the women listening to this genre; and the proportion of men who listened to Sufi music was found to be higher than the rate of women listening to that genre. When the literature on this subject is examined, it is seen that the results of a study conducted by Odabaşı[33] on a total of 1028 people in Istanbul between 1994-1995 and examining the relations between music understanding and religious sentiment in Turkish Society are parallel to this finding. In the related research, folk music preferences differ according to sex; while the rate of folk music was $4.6 \%$ for females, and $19.7 \%$ in males. In addition, the female participants in the study mentioned that they did not prefer to listen to folk music because they did not address the feelings of this musical style. As a result, it can be said that there is a significant difference between the kind of music that is preferred and sex and that men prefer to listen to more traditional types of music than women. Apart from this, it seems that men prefer to listen to heavy metal music more. In one study, it was stated that heavy metal music shaped the worldviews, habits, moods, friendships, people and things they liked, and hopes for what they wanted to be, and it was not just a music preference, but especially for these male adolescents it played an important role in their life [2]. In another research conducted by Hansen and Hansen[21] to examine the relationship between music preference and individual differences in social judgments and personality traits, it is stated that individuals who enjoy heavy metal music are said to have higher macho attitudes than individuals who do not. In addition, it is also pointed out that the idea of emotional romanticism, which is often seen in pop music, cannot be seen in heavy metal and the sexuality in heavy metal music is based on lust and male taste [26].

It is believed that both children and adults have gendered opinions determined by culture, and there are gender differences with stereotypical beliefs based on sex, and therefore there may be significant differences between men and women in terms of music enjoyment and preferences. According to Russell [37], these differences can be seen more clearly in the case of particularly preferred genres. While women select softer genres such as mainstream pop, men prefer aggressive genres such as rap and heavy rock [37]. In addition, North, Hargreaves, and O' Neill[30] stated that in adolescence, men listen to music more to influence their friends, while women listen to music to express their emotional needs and themselves emotionally [31]. In general, the gender difference seen in music preferences are based on the idea of the social role of men as emotionally strong and of women as emotional [7].

Significant differences were found as a result of the statistical analyses made to determine the differences of the personality traits of the students based on the musical genres. According to the results, the neurotic personality characteristic showed a significant difference according to the Jazz and Blues music types, while those who preferred to listen to the Jazz and Blues music types were found to have a lower average score than the non-listening group. When the relevant literature is examined in this respect, it is seen that studies supporting the findings are available. For example, in the study of Prof. Adrian North with over 36,000 people and his extensive research around the world, it was found that music preferences were associated with personality traits, and accordingly, people who preferred classical, jazz, blues, and folk, which he defines as creative and complex music, are tolerant people [31]. Rentfrow and Gosling [35] define in their music preferences and personality studies that people who prefer to listen to music genres such as classical, jazz, blues and folk music, which are identified as intellectual-complex categories, are complaisant towards others. From this point on it can be said that those who tolerate negativities in relation to other people and tolerate negative life events exhibit fewer neurotic features. Apart from these, Barber and Barber [5] used jazz music for therapeutic purposes in reducing the problems experienced by university freshmen. The "jazz for success" project made positive changes in the students. It was observed that the concentration and positive feelings of the students increased, and that the pain, sadness and depression decreased. Thanks to this project, students expressed that they felt better, that they regarded themselves as overcoming negative emotions and that it helped the development of their self-confidence. This information can be interpreted as a decrease in the neurotic levels of people because the music they listen to has a positive effect on the individual.

One of the results of data analysis is that the Extroversion personality trait is significantly different in the Turkish Classical Music and Slow music types; Turkish Classical Music and Slow music listeners' average score for extroversion is higher than in the non-listener group. When the relevant literature is examined, it is noteworthy that there are studies supporting this finding. For example, in a study of the relationship between loneliness of students and the type of music they listened to [20], the group with the lowest loneliness score was 
identified as the students who listened to Turkish Classical Music. In another study conducted in parallel with this finding, it was found that the individuals who preferred to listen to rap and arabesque music were not able to establish warm and sincere relations with the individuals in their surroundings and that they were inadequate in determining their own life purposes, while on the other hand, it was found that listeners of Turkish Classical and Turkish Folk music were more autonomous than listeners of other types of music, and that they were aware of their capacities, open to new experiences and perceived themselves more positively [42]. Based on this information, it can be said that the individuals who prefer to listen to Turkish Classical music are those who have no sense of disability and are successful in social relations and are outgoing and extrovert.

Another result of the study is that the Experiential openness personality characteristics were significantly different according to Turkish Classical Music, Western Classical Music, Sufi and Slow types, and that the average of the experimental openness point of individuals who preferred to listen to such music was higher than in non-listening individuals. When the related literature is examined, it is observed that there are studies supporting this finding. In his study of influencing factors on psychological well-being, Sezer[42] refers to the fact that listeners of Turkish Classical music are more autonomous, more aware of their capacities, open to new experiences, and more positively perceived individuals than others. Rentfrow and Gosling [35] describe individuals who prefer to listen to classical music, jazz, blues and folk music, which they identify as an intellectual-complex category in their study on music preferences and personality traits, as individuals who exclude conservative ideas. This can be interpreted as the fact that these people are open to different experiences.

According to the results of analysis, individuals who prefer to listen to Turkish Classical Music, Sufi and Slow music were found to have higher scores for the compatibility personality score than the non-listening group. Individuals who prefer to listen to classical music and Sufi music were found to have the highest anger control score in a research [41] that tries to determine whether the music the individual prefers to listen in everyday life affects the anger of the individual and their psychological status. This shows that individuals who prefer this type of music are more successful in controlling their anger than those who prefer other types of music. This result supports the high level of compatibility personality of the individuals who listen to such music.

Results of the study show that individuals who prefer to listen to Sufi and Slow music tend to have higher scores for the responsibility personality trait than the non-listening group. Sufi music is a kind of music made in accordance with the philosophy of Sufism in Islam, not to entertain but to make people realize the purpose of God. It is the expression of religious feelings. It is known that such music arouses peace, good morals and ethical feelings in individuals. In this context, sensitive and responsible individuals who are aware of what they are doing and who are trying to acquire good morals in the awareness of their words and behaviors may be inclined to listen to such music.

\section{Conclusions and Recommendations}

Music, a social phenomenon, together with the latest technological developments, has an important place especially in the lives of young people. Along with the choice of listening to music, it also results in socially existent action. Many listeners have a strong identification with certain musical genres and show their commitment to this genre in different social settings. People try to support and reinforce the qualities and views they carry, and the music they choose that they see fit for them serves this purpose [3]. As a matter of fact, the research results show that regardless of the degree of the effect of the research, there is a close connection between the individual's musical preferences and certain personality traits $[19,41$, $29,24,15]$ In other words, it can be said that individuals prefer music that is suitable for their own personality structures.

Music has many positive effects on creatures that it is hard to count them. Playing an instrument or participating in a music program at school was found to have broad positive effects on learning, motivation or behavior [12]. It is also known that music today has many benefits in many ways, such as the development of intelligence and language skills, the therapeutic effect, increased production capacity and efficiency, and in accelerating learning. Music therapy applications, defined as "the systematic use of music to achieve desired changes in behavior in a therapeutic environment directed by music therapists, used to reach therapeutic targets for the acquisition, maintenance and correction of mental and physical health" (American Musical Therapy Association, 1980), are known to have been used in order to provide individuals with the means to overcome the problems of behavior and mental problems, communication and self-confidence. From this point it will be useful to use this aspect of music especially in the education of students who need psychological support and to promote relaxation in the music genres found to be particularly positive on anger and psychological symptoms and to encourage our young people to listen to this music.

In addition to these, in some studies it is stated that some musical genres can create negative emotions in the individuals. For example, those who prefer arabesque and heavy metal types (hard rock, classical rock, rap, etc.) are more apt to commit suicide, experience more 
psychological chaos, are more angry and aggressive and have more emotional problems than those who do not prefer those kinds [18, 40,47] and listening to them will make them experience behavioral problems at school, use drugs and alcohol, and tend to commit crime [44]. It will be beneficial in terms of psychological health to encourage young people to listen to music types that are relaxing rather than depressing, nerve-wracking, aggressive, negative, and violent.

Because the studies in our country, especially about the relations between music interest and personality traits, are very few, this study can provide the source for other long-term studies and contribute to new scientific studies related to the subject. In addition to this, similar research can be replicated in consideration of the regional differences in our country and associated with different personality traits in these regions.

\section{REFERENCES}

[1] Akça, R. P. and Şenol, V. (2012). The effects of music, advertisement and mass media on adolescents, Academic Sight International Refereed Online Journal, 28, 1-19.

[2] Arnett, J. (1991). Heavy metal music and reckless behavior among adolescents. Journal of Youth and Adolescence, 20, 573-592.

[3] Artemiz, B. (2009). The investigation of the relationship between the adolescents' personalities and their interests in different music genres, Unpublished Master's Thesis, Institute of Social Sciences, Maltepe University, Istanbul, Turkey.

[4] Bacanl1, H., İlhan, T. and Aslan, S. (2009). Development of a personality scale based on five factor theory: adjective based personality test (ABPT), The Journal of Turkish Educational Sciences,7(2), 261-279.

[5] Ballard, M. E., Dodson, A. R. And Bazzini, D. G. (1999). Genre of music and lyrical content: Expectation effects. The Journal of Genetic Psychology,160(4): 476-487.

[6] Barber, N.L. and Barber, J.L. (2005). Jazz for success: Alternative music therapy to enhance student development in college, Journal of College and University Student Housing, 33(2), 4-9.

[7] Boer, D., Fischer R., Tekman H. G., Abubakar A., Njenga J. and Zenger M. (2012). Young people's topography of musical functions: Personal, Social and cultural experiences with music across genders and six societies. International Journal of Psychology, 47, 355-369.

[8] Bozkurt, S. S., Zahal, O. and Uyan, Z.D. (2015). Investigation of the kinds of music that middle school students listen to according to their emotional states. The Journal of Academic Social Science Studies, 39, 541-567.

[9] Brandley, I. (1972). Effect on student musical preference of a listening program in contemporary art music. Journal of Research in Music Education, 20(3), 344-353.
[10] Bulut, D. and Altay, E. (2012). Musical profiles of second level students in primary education: sample of Yozgat city, Kastamonu Education Journal, 20 (1), 237-254.

[11] Bülbül, K. (2016). The relationship between high school students' substance abuse proclivity with family structure, attachment style and hopelessness. Unpublished Master's Thesis, Institute of Educational Sciences, Karadeniz Technical University, Trabzon, Turkey, Trabzon.

[12] Campbell, P.S. (2002). Early childhood musical development. In L. Bresler and C. Thompson, The arts in children's lives (pp. 57-71). Dordrecht, The Netherlands: Kluwer Academic

[13] Ceyhun, C., Oğuztürk, Ö. and Ceyhun, A. G. (2001). The reliability and validity of substance abuse proclivity scale, Klinik Psikiyatri, 4, 87-93.

[14] Dollinger, S. J. (1993). Research note: Personality and music preference: Extraversion and excitement seeking or openness to experience? Psychology of Music, 21(1), 73-77.

[15] Devlin, J.M. and Seidel, S. (2009). Music preferences and their relationship to behaviors, beliefs, and attitudes toward aggression. (Online submission to Eric.ed.gov).

[16] Field, A. (2013). Discovering statistics using IBM SPSS (4th ed.), London, UK: Sage.

[17] Fraenkel, J. R., Wallen, N.E., \& Hyun, H. H. (2012). How to design and evaluate research in education (8th ed.). New York, NY: McGraw-Hill.

[18] Güner, N. (1995). The Effects of music to depression and aggression level of adolescents, Unpublished Master's Thesis, Institute of Socişal Sciences, Hacettepe University, Ankara, Turkey.

[19] Güner, N. (1998). The relationship between the type of music they listen and the level of aggression of adolescents, VII. National Educational Science Congress, Konya, 1, 291-299.

[20] Güven, E. (2017). Relationship between levels of loneliness and types of music listened to by fine arts high school students. Elementary Education Online, 16 (3), 1247-1261.

[21] Hansen, C. H. and Hansen, R. D. (1991). Constructing personality and social reality through music: Individual differences among fans of punk and heavy metal music. Journal of Broadcasting \& Electronic Media, 35(3), 335-350.

[22] Hansen, C. H. and Hansen, R. D. (1991). Schematic information processing of heavy metal lyrics. Communication Research, 18, 373-411.

[23] Kaşar, K. and Yöndem, S. (2006). Classical guitar knowledge and to take into consideration of attitude muğla university students, Muğla University Journal of Social Sciences, 16.

[24] Kelly D. Schwartz, K. and Fouts, T. G. (2003). Music preferences, personality style and developmental issues of adolescents. Journal of Youth and Adolescence, 32, (3), 205-213.

[25] King, P. (1988). Heavy metal music and drug abuse in adolescents. Postgraduate Medicine, 83(5), 295-304. 
[26] Krenske. L. and McKay, J. (2010). Hard and heavy: Gender and power in a heavy metal music subculture, Gender, Place \& Culture: A Journal of Feminist Geography, 7, 287-304.

[27] MacAndrew, C. (1986). Toward the psychometric detection of substance misuse in young men: The SAP Scale. Journal of Studies on Alcohol, 47(2), 161-166.

[28] Martin, G., Clarke, M. and Pearce, C. (1993). Adolescent suicide: Music preference as an indicator of vulnerability. Journal of the American Academy of Child \&Adolescent Psychiatry, 32(3), 530-535.

[29] Mills, B. D. (1996). Effects of music on assertive behavior during exercise by middle-school-age students. Perceptual and Motor Skills, 83, 2.

[30] North, A. C., Hargreaves, D. J., and O'Neill, S. A. (2000). The importance of music to adolescents. British Journal of Educational Psychology, 70(2), 255-272.

[31] North, A. C., Desborough, L. and Skarstein, L. (2005). Musical preference, deviance, and attitudes towards celebrities. Personality and Individual Differences, 38, 1903-1914.

[32] North, A. C. and Hargreaves D. J. (2008). The social and applied psychology of music, Oxford University Press, New York.

[33] Odabaşı, F. (2001). The Relationship between the music and entertainment and the religious feeling in Turkish society: Example of Istanbul, Unpublished Master's Thesis, Institute of Social Sciences, Marmara University, Istanbul, Turkey.

[34] Ögel, K., Ermağan E., Eke, C.Y. and Taner, S. (2007). A comparison between drug experimenters and non-experimenters regarding their participation to the social activities: Istanbul sample, Journal of Dependence, 8(1), 18-23.

[35] Rentfrow, P. J. and Gosling, S. D. (2003). The Do Re Mi's of everyday life: The structure and personality correlates of music preferences. Journal of Personality and Social Psychology, 84(6), 1236 -1256.

[36] Roberts, K. R., Dimsdale, J., East, P. and Friedman, L. (1998). Adolescent emotional response to music and its relationship to risk-taking behaviors. Journal of Adolescent Health, 23(1),1-2.

[37] Russell, P. A. (1997). Musical tastes and society. The Social Psychology of Music, Oxford University Press, 141-158.

[38] Sağır, A. and Öztürk, B. (2015). The context of sociological identity and music: The case of Karabuk university. Ușak University Journal of Social Sciences, 8(2), 121-154.

[39] Sakar, M. H. and Maba, A. (2015). Musical preferences and listening practice of secondary school students, The Journal of International Social Research, 36, 980-996.

[40] Scheel, K. R. and Westefeld, J. S. (1999). Heavy metal music and adolescent suicidality: An empirical investigation. Adolescence, 34, 253-273.

[41] Sezer, F. (2011). The effects of music on anger and psychological symptoms, International Journal of Human
Sciences, 8(1), 1472-1493.

[42] Sezer, F. (2013). Factors that affect psychological well-being, E-Journal of New World Sciences Academy, 8(4), s.489-504.

[43] Tabachnick, B. G. and Fidell, L. S. (2013). Using Multivariate Statistics (6th ed.). USA: Pearson

[44] Took, K. J. and Weiss, D. S. (1994). The relationship between heavy metal and rap music and adolescent turmoil: Real or artifact? Adolescence, 29, 613-621.

[45] Ulutürk, N. (2008). Music types that the students at Anatolian High School of Fine Arts prefer to listen, Unpublished Master's Thesis, Institute of Social Sciences, Institute of Social Sciences, Abant İzzet Baysal University, Bolu, Turkey

[46] Wass, H., Raup, J. L. and Cerullo, K. (1989). Adolescents' interest in and views of destructive themes in rock music. OMEGA - Journal of Death and Dying, 19(3). 177-186.

[47] Yağışan, N. (2013). Musical preferences of university students and the correlation of these preferences with aggressiveness. SED Journal of Art Education, 1(2), 96-113.

[48] Yalch R. and Spangenberg, E. (1990). Effects of store music on shopping behavior. Journal of Consumer Marketing, 7(2), 55-63.

[49] Yaylal1, M. (2006). Research on socio-economic profile of university youth. Erzurum: Atatürk University Press.

[50] Mulder, J., Ter Bogt, T. F., Raaijmakers, Q. A., Gabhainn, S. N., Monshouwer, K., \& Vollebergh, W. A. (2009). The soundtrack of substance use: music preference and adolescent smoking and drinking. Substance Use \& Misuse, 44(4), 514-531.

[51] Frith, S. (1996). Music and identity. Questions of cultural identity, 1, 108-128. 